\title{
3 Research Square

\section{The Spatial Variations of Water Quality and Effects of Water Landscape in Baiyangdian Lake, North China}

Liqing Li ( $\square$ lilq@cug.edu.cn )

China University of Geosciences School of Environmental Studies

\section{Xinghong Chen}

China University of Geosciences School of Environmental Studies

\section{Meiyi Zhang}

Research Centre for Eco-Environmental Sciences Chinese Academy of Sciences

\section{Weijun Zhang}

China University of Geosciences School of Environmental Studies

\section{Dongsheng Wang}

RCEES: Research Centre for Eco-Environmental Sciences Chinese Academy of Sciences

\section{Hongjie Wang}

Hebei University

\section{Research Article}

Keywords: Baiyangdian Lake, Water quality, Landscape, Variation

Posted Date: July 23rd, 2021

DOl: https://doi.org/10.21203/rs.3.rs-609387/v1

License: (9) (i) This work is licensed under a Creative Commons Attribution 4.0 International License. Read Full License

Version of Record: A version of this preprint was published at Environmental Science and Pollution Research on October 16th, 2021. See the published version at https://doi.org/10.1007/s11356-02116938-0. 


\section{Abstract}

Baiyangdian Lake (BYD), a large shallow lake in North China, has complex water landscape patterns that are underlies spatial variations in water quality. In this study, we collected 61 water samples from three water landscapes (reed littoral zones, fish ponds and open water) and analyzed them for water quality parameters, such as dissolved organic carbon (DOC), total nitrogen (TN), and total phosphorus (TP). Water landscape distribution (determined using remote sensing imagery) was then used to assess correlations between water quality parameters and water landscape proportion in differently scaled buffer zones. There was substantial variation across all subareas, with TN and TP concentrations ranging from $0.90-4.10 \mathrm{mg} / \mathrm{L}$ and $0.06-0.18 \mathrm{mg} / \mathrm{L}$, respectively. Spatial variations in water quality were mainly caused by water landscape distribution and external nutrient inputs. There were negative correlations between DOC, TN, and TP concentrations and the area proportion of reed littoral zones in the 300 and $500 \mathrm{~m}$ buffers. In contrast, DOC, TN and TP concentrations were significantly positively correlated with the area proportion of fish ponds in the $100 \mathrm{~m}$ buffer. Furthermore, compared with reed littoral zones, a lower nitrogen to phosphorus ratio and a higher proportion of dissolved organic nitrogen and tyrosine-like proteins were found in fish ponds. These effects were mainly attributed to development of internal sediment loadings due to nutrient exchange between sediment and overlying water. Therefore, dredging-based sediment removal from fish ponds should be considered to suppress internal phosphorus loading and accelerate recovery of the BYD ecosystem.

\section{Introduction}

Eutrophication of aquatic ecosystems is a global environmental concern, especially in freshwater lakes (Huisman et al. 2018, Tu et al. 2019). In recent years, many efforts have been made to reduce external nutrient loads across whole watersheds and remove internal nutrient recycling from bottom sediments (Chen et al. 2020, Horppila 2019, Lurling and Faassen 2012). Identifying the effects of sediments nutrient release on the overlying water quality is necessary to effectively implement dredging of nutrient-rich sediment. However, previous studies have often focused on the diffusion flux of nitrogen and phosphorus in sediments-water interfaces to determine the internal source impacts (Yang et al. 2020, Yu et al. 2016). Few studies have identify the potential impacts of bottom-sediments nutrient release to overlying water, by examining the spatial variations of in water quality and nutrient processes at water landscape type.

BYD, the largest freshwater lake in the North China Plain, is located in Anxin County, Hebei Province, with an average water depth of 2-3m and an approximate area of $366 \mathrm{~km}^{2}$ (Wang et al. 2014). This area is the planned center of a new special economic zone (the Xiongan New Area), for which the lake is expected to play an important role in supplying fresh water, controlling floods, regulating the local climate, and maintaining biodiversity for the region. However, over the past several decades, it has suffered severe pollution from industrial wastewater, domestic sewage, and agricultural runoff, as well as extensive pondbased aquaculture, due to regional population growth and economic development (Han et al. 2020, Hu et al. 2012). Although its water quality has been somewhat improved recently through reductions in external 
nutrient loading and prohibitions on aquaculture, eutrophication remains a problem, especially in summer.

The implementation of higher water quality requirements in the area make it necessary to further improve BYD's water quality and comprehensively restore its aquatic ecology. In many previous shallow lake restorations where external nutrient loading was reduced, sediment internal nutrient loading was likely to recycle nutrients back to the overlying water, preventing improvements in water quality (Welch and Cooke 2005). Previous studies have shown that large amount of nutrients are accumulated in BYD's sediments(Ji et al. 2019, Zhu et al. 2019), leading to proposals to remove such nutrient-rich sediments by dredging in order to mitigate internal nutrient impacts and accelerate lake recovery.

Dredging limits can be determined either by investigating the spatial accumulation patterns of sediment nutrients or by identifying internal nutrient release fluxes to the overlying water (Ji et al. 2019, Zhu et al. 2019). Both methods are time-intensive, low-precision, and limited in the number of monitoring sites. However, spatial variations in water quality can be also used to determine the effects of sediment internal nutrients on overlying water in order to define dredging limits, especially for large lakes with highly fragmented landscape patterns BYD (Varol 2020). Such variations are not only associated with the watershed landscape patterns, but can also be directly impacted by aquatic conditions and process (Mainali and Chang 2018, Nobre et al. 2020). These patterns have critical influences on hydrological processes, energy flows and nutrient inputs, leading to spatial variations in water quality (Lee et al. 2009, Xie et al. 2018).

Furthermore, water landscape composition also underlies spatial variations in water quality in large lakes. Many studies have shown that reed littoral zones in large shallow lakes can reduce the aquatic nitrogen and phosphorus concentration through complex biochemical processes such as sedimentation, plant assimilation, and microbial denitrification (Wang et al. 2017). In contrast, large-scale enclosure fishing in lakes increases nutrient concentrations and leads to water quality variations. Fish ponds have high nitrogen and phosphorus content, high algal density due to the addition of fish feed, and the accumulation of nutrients in the sediment (Herbeck et al. 2013). These effects are associated with internal sediment nutrient release that are dominated by biogeochemical processes (Markovic et al. 2019, Parsons et al. 2017). In areas with significant internal releases, organic matter mineralization in the sediment can form anoxic and anaerobic environments that release phosphorus and denitrify at the same time, resulting in the relative enrichment of phosphorus and the reduction of the nitrogen to phosphorus ratio in the overlying water (Zhang et al. 2018).

In this study, we assessed spatial variations in water quality in order to explore differences between water landscape type and the impacts of internal pollution in BYD. Our specific research objectives were to (1) determine spatial differences in water quality and the influence of water landscape type on water quality; (2) assess differences in the fluorescence components of dissolved organic matter, composition of nitrogen and phosphorus and the ratio of nitrogen to phosphorus in water landscape type; and (3) discuss the impact of sediment internal pollution on water quality. 


\section{Methodology \\ 2.1. Study area}

BYD is surrounded by dikes and dams within terrain that gradually slopes from northwest to southeast. It lies within the Daqing River basin, which collects water from eight rivers, including Xiaobai River (XB), Zhulong River (ZL), Xiaoyi River (XY), Tang River (TH), Fu River (FH), Cao River (CH), Ping River (PH), and Baigouying River (BGY) (Fig. 1). FH is the main inflow river of BYD, carrying a large amount of sewage at the same time. The area has a semi-arid temperate continental monsoon climate with an average annual temperature range of $7.3-12.7^{\circ} \mathrm{C}$ and average annual precipitation of $564 \mathrm{~mm}, 80 \%$ of which occurs in July and August (Xia et al. 2012).

\subsection{Subarea delineation and Landscape pattern composition}

We assessed $315.54 \mathrm{~km}^{2}$ of the BYD area, dividing this into nine subareas by geographical location and water quality characteristics, including FH, Zaozhaidian (ZZ), Nanliuzhuang (NL), Shaochedian (SC), Duancun (DC), Diantou (DT), Caiputai (CP), Quantou (QT) and Zaolingzhuang (ZL) (Fig. 1). We used visual interpretation of GF2 imagery (4 m resolution) within ArcGIS to define eight landscape types: 1.6 $\mathrm{km}^{2}$ of entertainment land, $15.6 \mathrm{~km}^{2}$ of residential land, $24.2 \mathrm{~km}^{2}$ of paddy field, $78.1 \mathrm{~km}^{2}$ of dry land, 0.4 $\mathrm{km}^{2}$ of woodland, $105.9 \mathrm{~km}^{2}$ of reed littoral zones, $42.1 \mathrm{~km}^{2}$ of fish ponds, and $47.3 \mathrm{~km}^{2}$ of open water (Fig. 1). Then, reed littoral zones, fish ponds and open water are also water landscape, which constitute the waters area of BYD. Due to the long-term discharge of sewage in the $\mathrm{FH}$, the water pollution there is serious, so in order to better analyze the spatial variations and influence of the water landscape on the water quality, $\mathrm{FH}$ is also considered to be both an independent subarea and a special water landscape. Most of BYD's 345 fish ponds were located in ZL, CP, QT, and DT. The reed-vegetation ecotone was large, with intermingled reed littoral zones, villages, and fish ponds, constituting a unique landscape.

\subsection{Water sampling and analytical methods}

The 61 sampling sites were selected from the nine subareas in October 2019 (Table 1, Fig. 1). These sites were then discretized into three individual groups by landscape type: open water $(n=26)$, reed littoral zones $(n=16)$, and fish ponds $(n=19)$. All samples were collected at $\sim 0.5 \mathrm{~m}$ below the water surface, within a period of three days, then saved in a high-density polyethylene container and filtered using 0.45$\mu \mathrm{m}$ Millipore nitrocellulose membrane filters within $24 \mathrm{hr}$. 
Table 1

Distribution of sampling sites by landscape type and subarea.

\begin{tabular}{|lllll|}
\hline Subareas & Open water & Reed littoral zones & Fish ponds & Total \\
\hline FH & 4 & 0 & 0 & 4 \\
\hline ZZ & 0 & 2 & 0 & 2 \\
\hline SC & 5 & 3 & 2 & 10 \\
\hline NL & 2 & 3 & 2 & 7 \\
\hline DC & 3 & 0 & 2 & 5 \\
\hline DT & 4 & 2 & 2 & 8 \\
\hline CP & 3 & 2 & 3 & 8 \\
\hline QT & 3 & 2 & 4 & 9 \\
\hline ZL & 2 & 2 & 4 & 8 \\
\hline Total & 26 & 16 & 19 & 61 \\
\hline
\end{tabular}

Eighteen water quality parameters were monitored and analyzed, including water temperature $\left(\mathrm{T},{ }^{\circ} \mathrm{C}\right), \mathrm{pH}$, electrical conductance $(E C, \mu \mathrm{s} / \mathrm{cm})$, dissolved oxygen ( $\mathrm{DO}, \mathrm{mg} / \mathrm{L})$, redox potential (ORP, mv), dissolved organic matter (DOM) fluorescence properties, dissolved organic carbon (DOC, mg/L), total nitrogen (TN, $\mathrm{mg} / \mathrm{L})$, particulate Organic nitrogen (PON, $\mathrm{mg} / \mathrm{L}$ ), dissolved nitrogen ( $\mathrm{DN}, \mathrm{mg} / \mathrm{L})$, ammonia nitrogen $\left(\mathrm{NH}_{4}{ }^{+}-\mathrm{N}, \mathrm{mg} / \mathrm{L}\right)$, nitrate nitrogen $\left(\mathrm{NO}_{3}{ }^{-}-\mathrm{N}, \mathrm{mg} / \mathrm{L}\right)$, dissolved Organic nitrogen (DON, $\left.\mathrm{mg} / \mathrm{L}\right)$, total phosphorus (TP, mg/L), particulate phosphorus (PP, mg/L), dissolved phosphorus (DP, $\mathrm{mg} / \mathrm{L}$ ), dissolved Organic phosphorus (DOP, mg/L), soluble reactive phosphorus (SRP, mg/L). T, $\mathrm{pH}, \mathrm{EC}, \mathrm{DO}$ and ORP were measured in situ using a portable multiparameter water quality instrument. DOC was determined using high temperature catalytic oxidation with a total organic carbon analyzer (TOC-VCPH, Shimadzu, Japan). $\mathrm{TN}, \mathrm{DN}, \mathrm{NH}_{4}{ }^{+}-\mathrm{N}, \mathrm{NO}_{3}{ }^{-}-\mathrm{N}, \mathrm{TP}, \mathrm{DP}$, and SRP were determined by standard methods suggested by the State Environmental Protection Administration of China (SEPA, 2002).

The DOM fluorescence properties were measured using a fluorescence spectrophotometer (Hitachi F97, Japan) with a $150 \mathrm{~W}$ xenon excitation source. The excitation (ex) wavelength scanned between 200-450 $\mathrm{nm}$ and the emission (em) wavelength scanned between $250-550 \mathrm{~nm}$, with a scanning speed of 12,000 $\mathrm{nm} / \mathrm{min}$. The excitation and emission wavelength increments were 5 and $1 \mathrm{~nm}$, respectively. All 3D-EEM analyses were conducted using quartz cells with a $1 \mathrm{~cm}$ path length and corrected using a Milli-Q blank to eliminate the effects of Raman scatter. All samples were diluted with Milli-Q water to control UV254 to < $0.05 / \mathrm{cm}$ to eliminate the inner filter effect in the fluorescence measurements. PARAFAC analysis of the EEM datasets for the 61 samples was conducted using the DOM Flour toolbox of the Matlab software package, which can decompose the EEM spectrum into relatively independent fluorescent components and perform residual errors and split-half diagnostics. Finally, up to five components (two classes of 
aromatic protein-like materials, fluvicacid-like materials, microbial by-product-like materials, and humic acid-like materials) were separated (Lv et al. 2019).

\subsection{Statistical methods}

We examined correlations between water quality parameters and the area proportion of water landscape types (reed littoral zones, fish ponds and open water) in differently sized buffers. Using the sampling points as samples, circular buffers were extracted using a buffering tool in ArcGIS version 10.2 (Fig. 2). We selected three buffer sizes $(100,300$, and $500 \mathrm{~m})$ to identify the correlations by considering the distance between sampling sites and lake area, providing multiple spatial scales for exploring these relationships.

The area percentages of the three water landscape types by different buffer scales were calculated using ArcGIS and Excel. Spearman rank correlation analysis was used for bivariate analysis of water quality parameter concentrations and area proportions of landscape types in the multivariate statistical analysis software SPSS statistic 21 . The two-sided test method was chosen for significance tests.

ANOVA was used to determine if spatial difference of water quality and the influence of water landscape type on water quality were statistically significant. Tukey test was used to determine differences among means, and significance was accepted at $p<0.05$.

\section{Results}

\subsection{Spatial variations in water quality}

In addition to $\mathrm{NH}_{4}{ }^{+}-\mathrm{N}$, the other eight water quality parameters, including $\mathrm{TN}, \mathrm{NO}_{3}{ }^{-}-\mathrm{N}, \mathrm{DOC}, \mathrm{TP}, \mathrm{SRP}, \mathrm{PP}, \mathrm{pH}$ and EC, showed significant differences across the nine subareas (Table 2, Fig. 3). TN concentrations ranged from $0.90-4.10 \mathrm{mg} / \mathrm{L}$ (mean $1.86 \pm 0.95 \mathrm{mg} / \mathrm{L}$ ), with highest values in $\mathrm{FH}$, followed by $Z Z, N L, D T$, $\mathrm{CP}, \mathrm{QT}, \mathrm{ZL}$, and SC. $\mathrm{NO}_{3}{ }^{-}-\mathrm{N}$ concentrations ranged from $0.15-3.49 \mathrm{mg} / \mathrm{L}$ (mean $1.00 \pm 1.07 \mathrm{mg} / \mathrm{L}$ ), also with highest values in $\mathrm{FH}$. These decreased eastward and southward toward the minimum concentration in $\mathrm{ZL}$. $\mathrm{NH}_{4}{ }^{+}-\mathrm{N}$ concentrations ranged from $0.32-0.55 \mathrm{mg} / \mathrm{L}$ (mean $0.41 \pm 0.08 \mathrm{mg} / \mathrm{L}$ ), with no significant difference between the 9 subareas.

As with the spatial variations of $\mathrm{TN}$ and $\mathrm{NO}_{3}{ }^{-}{ }^{-} \mathrm{N}$, TP and SRP concentrations were also highest in $\mathrm{FH}$, decreasing eastward and southward toward their minimum concentrations in SC. In contrast to TN and TP, concentrations of DOC, $\mathrm{pH}$ and EC were lowest in FH and increased eastward and southward, reaching highest concentrations in the QT subarea. 
Table 2

Analysis of Variance (ANOVA) Results for water quality in different subareas

\begin{tabular}{|c|c|c|c|c|c|c|c|c|c|c|}
\hline \multirow[t]{2}{*}{ Water quality } & \multirow{2}{*}{$\begin{array}{l}\text { ANOVA } \\
\text { p-value }\end{array}$} & \multicolumn{9}{|c|}{ Subareas } \\
\hline & & $\mathrm{FH}$ & ZZ & NL & SC & $\mathrm{DC}$ & DT & $\mathrm{CP}$ & QT & ZL \\
\hline TN & $<0.001$ & a & $b$ & bc & c & bc & bc & bc & $\mathrm{bc}$ & bc \\
\hline $\mathrm{NO}_{3}^{-}-\mathrm{N}$ & $<0.001$ & a & b & bc & c & bc & c & c & c & c \\
\hline $\mathrm{NH}_{4}^{+}-\mathrm{N}$ & 0.422 & a & a & a & a & a & a & a & a & a \\
\hline TP & 0.041 & a & $a b$ & $a b$ & c & bc & $a b$ & $a b$ & $\mathrm{bc}$ & bc \\
\hline SRP & $<0.001$ & a & a & $b$ & bc & bc & bc & $\mathrm{bc}$ & $\mathrm{bc}$ & c \\
\hline PP & 0.031 & a & c & $a b$ & c & bc & $a b$ & $a b$ & $b c$ & bc \\
\hline DOC & $<0.001$ & c & $\mathrm{bc}$ & c & bc & bc & bc & bc & a & $a b$ \\
\hline $\mathrm{PH}$ & $<0.001$ & c & $b$ & $a b$ & $a b$ & $a b$ & a & $b$ & a & $a b$ \\
\hline EC & $<0.001$ & c & c & c & bc & $\mathrm{a}$ & $a b$ & $a b$ & a & $a b$ \\
\hline
\end{tabular}

\subsection{Influences of water landscape type on water quality}

Correlation analysis between 11 water quality parameters (T, pH, EC, DO, DOC, TN, PON, $\mathrm{NH}_{4}{ }^{+}{ }^{-} \mathrm{N}, \mathrm{NO}_{3}{ }^{-}-\mathrm{N}_{\text {, }}$ DON and TP) and area proportion of landscape type (reed littoral zones, open water and fish ponds) by 100, 300, and 500 m buffers (Fig. 4) showed negative correlations between all but $\mathrm{NH}_{4}{ }^{+}-\mathrm{N}$ and the area proportion of reed littoral zones for the $300 \mathrm{~m}$ and $500 \mathrm{~m}$ buffers. Open water generally contributed to the concentrations of DO, DOC, TN, PON, and $\mathrm{NH}_{4}{ }^{+}-\mathrm{N}$ for the $300 \mathrm{~m}$ and $500 \mathrm{~m}$ buffers. In contrast, the concentrations of $\mathrm{DO}, \mathrm{DOC}, \mathrm{TN}, \mathrm{PON}, \mathrm{DON}, \mathrm{NO}_{3}{ }^{-}{ }^{-} \mathrm{N}$, and TP were significantly positively correlated with the area proportion of fish ponds for the $100 \mathrm{~m}$ buffer.

There were significant differences in some (TN, $\mathrm{NO}_{3}{ }^{-}-\mathrm{N}, \mathrm{TP}, \mathrm{PP}, \mathrm{SRP}, \mathrm{DOC}, \mathrm{pH}$ and EC) but not all $\left(\mathrm{NH}_{4}{ }^{+}-\mathrm{N}\right)$ parameters among the four water landscape types of $\mathrm{FH}$, open water, reed littoral zones, and fish ponds (Table 3, Fig. 5). TN concentrations were significantly lower in open water $(1.67 \pm 0.66 \mathrm{mg} / \mathrm{L})$, reed littoral zones $(1.07 \pm 0.34 \mathrm{mg} / \mathrm{L})$, and fish ponds $(1.66 \pm 0.70 \mathrm{mg} / \mathrm{L})$ than in $\mathrm{FH}(3.90 \pm 0.31 \mathrm{mg} / \mathrm{L})$. Similarly, $\mathrm{NO}_{3}{ }^{-}-\mathrm{N}$ concentrations were significantly lower in open water $(0.75 \pm 0.72 \mathrm{mg} / \mathrm{L})$, reed littoral zones $(0.35$ $\pm 0.20 \mathrm{mg} / \mathrm{L})$, and fish ponds $(0.40 \pm 0.28 \mathrm{mg} / \mathrm{L})$ than in $\mathrm{FH}(3.28 \pm 0.32 \mathrm{mg} / \mathrm{L})$. In contrast, $\mathrm{NH}_{4}{ }^{+}-\mathrm{N}$ concentration were no significant difference between the four water landscape types. 
TP concentrations were lower in open water $(0.09 \pm 0.03 \mathrm{mg} / \mathrm{L})$ and reed littoral zones $(0.09 \pm 0.05 \mathrm{mg} / \mathrm{L})$ than in fish ponds $(0.13 \pm 0.09 \mathrm{mg} / \mathrm{L})$ and $\mathrm{FH}(0.14 \pm 0.05 \mathrm{mg} / \mathrm{L})$. Similarly, PP concentrations were lower in open water $(0.04 \pm 0.03 \mathrm{mg} / \mathrm{L})$ and reed littoral zones $(0.04 \pm 0.04 \mathrm{mg} / \mathrm{L})$ than in fish ponds $(0.07 \pm 0.05$ $\mathrm{mg} / \mathrm{L})$ and $\mathrm{FH}(0.05 \pm 0.05 \mathrm{mg} / \mathrm{L})$. However, the highest SRP concentrations were found in $\mathrm{FH}(0.06 \pm 0.01$ $\mathrm{mg} / \mathrm{L})$, with lower concentrations in open water $(0.02 \pm 0.01 \mathrm{mg} / \mathrm{L})$, reed littoral zones $(0.02 \pm 0.02 \mathrm{mg} / \mathrm{L})$, and fish ponds $(0.02 \pm 0.03 \mathrm{mg} / \mathrm{L})$.

Fish ponds had the highest DOC concentrations $(12.23 \pm 4.38 \mathrm{mg} / \mathrm{L})$, open water $(8.54 \pm 2.24 \mathrm{mg} / \mathrm{L})$ and reed littoral zones $(8.58 \pm 2.07 \mathrm{mg} / \mathrm{L})$ were mid-level, and $\mathrm{FH}(5.70 \pm 0.52 \mathrm{mg} / \mathrm{L})$ was lowest. $\mathrm{EC}$ and $\mathrm{pH}$ followed the same trend as DOC.

Table 3

Analysis of Variance (ANOVA) Results for water quality of different water landscape types

\begin{tabular}{|c|c|c|c|c|c|}
\hline \multirow[t]{2}{*}{ Water quality } & \multirow{2}{*}{$\begin{array}{l}\text { ANOVA } \\
\text { p-value }\end{array}$} & \multicolumn{4}{|c|}{ water landscape type } \\
\hline & & $\mathrm{FH}$ & OW & RLZ & $\mathrm{FP}$ \\
\hline TN & $<0.001$ & a & $b$ & c & $\mathrm{b}$ \\
\hline $\mathrm{NO}_{3}^{-}-\mathrm{N}$ & $<0.001$ & a & $b$ & c & $\mathrm{C}$ \\
\hline $\mathrm{NH}_{4}{ }^{+}-\mathrm{N}$ & 0.487 & a & a & a & a \\
\hline TP & 0.043 & a & $b$ & $a b$ & $\mathrm{~b}$ \\
\hline SRP & 0.041 & a & $b$ & $b$ & $\mathrm{~b}$ \\
\hline PP & 0.015 & a & $b$ & $b$ & $\mathrm{~b}$ \\
\hline DOC & $<0.001$ & c & $b$ & $b$ & a \\
\hline $\mathrm{PH}$ & $<0.001$ & $b$ & a & a & a \\
\hline EC & $<0.001$ & $b$ & $b$ & $b$ & $a$ \\
\hline
\end{tabular}

\subsection{Effects of water landscape type on N:P,individual composition of nitrogen and phosphorus and DOM fluorescence components}

TN:TP, DN:DP, and $\mathrm{NO}_{3}{ }^{-}-\mathrm{N}: \mathrm{SRP}$ were all significantly affected by water landscape type (Fig. 6). TN:TP was highest for $\mathrm{FH}(29.5 \pm 9.2)$, followed by open water (19.8 \pm 7.8$)$, fish ponds $(15.7 \pm 6.6)$, and reed littoral zones (13.2 \pm 5.8$)$, and the same trend occurred for $\mathrm{DN}: \mathrm{DP}$ and $\mathrm{NO}_{3}{ }^{-} \mathrm{-N}$ :SRP. These results suggested that BYD has the ability to remove incoming nitrogen. In contrast, phosphorus appeared to be relatively enriched compared to nitrogen, while SRP concentrations were reduced in open water, fish ponds, and reed littoral zones. 
Figure6. Variations in (a) TN:TP, (b) DN:DP, and (c) $\mathrm{NO}_{3}{ }^{-} \mathrm{N}: \mathrm{SRP}$ for the four water landscape types

Variations in nitrogen and phosphorus composition were significantly affected by water landscape type (Fig. 7). The proportion of $\mathrm{NO}_{3}{ }^{-}-\mathrm{N}$ were significantly higer in $\mathrm{FH}$, open water and reed littoral zones than in the fish ponds. $\mathrm{NH}_{4}{ }^{+}-\mathrm{N}$ accounted for the highest and lowest proportion of $\mathrm{TN}$ in the reed littoral zones and $\mathrm{FH}$ respectively, and the proportion of $\mathrm{NH}_{4}{ }^{+} \mathrm{N}$ was not meaningfully different between open water and fish ponds. DON accounted for the highest proportion of TN in the fish ponds. Meanwhile, PON accounted for the highest proportion of TN in the fish ponds, declining in open water and reed littoral zones. SRP accounted for the highest and lowest proportion of TP in the FH and fish ponds, and the proportion of SRP had no significant difference between the open water and reed littoral zones. The proportion of PP was significantly lower in FH, open water and reed littoral zones than in fish ponds.

PARAFAC analysis separating the different 3D-EEM spectral components detected three main fluorescence components in BYD (Fig. 8). Component 1 and component 2 were indicative of the presence of tyrosine-like proteins (Pro\&) and tryptophan-like proteins (Pro\&) respectively, both of which could be produced by plankton death, and decomposition along with microbial metabolism. Component 3 was attributable to humic acid substances (HA), which could be decomposed as plant residues and not easily degraded or utilized by microorganisms (Zhao et al. 2016). The proportions of Pro I in fish ponds accounted for $39 \pm 11 \%$, significantly higher than in $\mathrm{FH}$, open water, and reed littoral zones (Fig. 9). In contrast, the proportions of $\mathrm{HA}$ in fish ponds were $23 \pm 15 \%$, significantly lower than those in $\mathrm{FH}$, reed littoral zones and similar to open water.

\section{Discussion}

The spatial variations in nutrients suggested that their input into BYD could be diluted and reduced across the whole lake. TN and TP concentrations in FH and NL were significantly higher than those in SC, DT, DC, CP, QT, and ZL subareas. FH was the main source of nitrogen and phosphorus for BYD, and these inputs contributed significantly to the higher TN and TP concentrations in NL. The lower TN and TP concentrations in the other subareas, which were further from FH's inputs, could be explained by ecological buffering capacity or resilience to nutrient inputs. Spatial variations within and between subareas can be further explained by unique landscape compositions and distributions. The water quality of fish ponds was significantly worse than open water and reed littoral zones. Variations in nitrogen and phosphorus composition and their ratio were likely dominated by biogeochemical processes (e.g., sedimentation, plant uptake, and microbial immobilization) (Markovic et al. 2019, Parsons et al. 2017), which differed in the three water landscape types.

Reed littoral zones covered $105.9 \mathrm{~km}^{2}, 54 \%$ of the total BYD waters area and were distributed throughout it. As aquatic terrestrial ecotones, these are hotspots for biogeochemical cycling of nitrogen and phosphorus in BYD. The reed littoral zones markedly reduced incoming nitrogen and lowered the N:P ratio in water, likely due to biological uptake and denitrification of nitrate (Wang et al. 2017). Consequently, the 
unique spatial distribution of reed littoral zones underlies the spatial differences and resilience of water quality in BYD.

Fish ponds covered $42.2 \mathrm{~km}^{2}, 22 \%$ of the total BYD waters area. Many hundreds of these ponds, with an average area of $0.12 \mathrm{~km}^{2}$, have been constructed by dividing and enclosing reed littoral zones or open water since the 1990s. They had higher TN and TP concentrations than the open water and reed littoral zones. Although they have not been used for fishing since 2017, they still affect water quality in the entire lake. The 30-year history of aquaculture, including inputs of fish feed, has increased nutrient availability (especially phosphorus and nitrogen) that supports high phytoplankton densities and has led to the development of sediments rich in organic matter and nutrients. Consequently, the high nutrient concentrations in fish ponds were likely due to the development of internal loadings, which recycle phosphorous back to the overlying water and exacerbate algal blooms. In addition, the low N:P ratio in these ponds can be further explained by complex biogeochemical processes in the sediments (Zhang et al. 2018). Phosphorus mineralized during organic matter decomposition is readily released from sediments, while denitrification in sediment is a major process removing available nitrogen. As a result, nutrient fluxes from sediment are relatively depleted in nitrogen compared to phosphorus, leading to declining N:P in fish ponds. Furthermore, compared with reed littoral zones and open water, a higher proportion of DON and Pro I was found in fish ponds, likely due to sediment organic matter mineralization and microbial and algal release (Lusk and Toor 2016, Meng et al. 2013). The elevated DON, in turn, could be a potential source of bioavailable $\mathrm{N}$ to phytoplankton and bacteria that cause water quality degradation (Lu et al. 2020).

Consequently, many fish ponds in BYD not only reduce its spatial resilience to nutrient inputs, but also serve as a source of biodegradable organic nitrogen and increase the ecological risk when water is discharged or exchanged. Therefore, fish ponds are a major challenge for the recovery of water quality in BYD. The key to effectively improving water quality and ecological resilience here is to restore the physical environment from fish ponds to open water. Sediment removal by dredging in fish ponds should be considered to suppress internal phosphorus loading and accelerate lake recovery.

\section{Conclusions}

Our analysis of water quality parameters from 61 samples across three water landscapes of BYD showed substantial variations across nine subareas. TN and TP concentrations ranged from $0.90-4.10 \mathrm{mg} / \mathrm{L}$ and $0.06-0.18 \mathrm{mg} / \mathrm{L}$, respectively. These spatial variations were mainly caused by the distribution of different water landscape types and external nutrient inputs. Reed littoral zones were capable of reducing nitrogen and phosphorus concentrations, while fish ponds had higher nitrogen and phosphorus concentrations, resulting in lower water quality. Furthermore, compared with reed littoral zones and open water, fish ponds had lower N:P ratios and higher proportions of DON and Pro I. These effects were mainly attributed to internal sediment nutrient release, dominated by biogeochemical processes. Therefore, sediment removal by dredging in fish ponds should be considered to suppress internal phosphorus loading and to accelerate water quality recovery in BYD. 


\section{Declarations}

Authors Contributions All authors contributed to the study conception and design. Liqing Li gave the idea of this research work. Material preparation, data collection and analysis were performed by Liqing Li and Xinghong Chen. The first draft of the manuscript was written by Liqing Li and Xinghong Chen. Meiyi Zhang, Weijun Zhang, Dongsheng Wang and Hongjie Wang helped the work with his ideas and made a critical editing and reviewing of the whole manuscript. All authors read and approved the final manuscript.

Funding This research was supported by the Major Science and Technology Program for Water Pollution Control and Treatment (2018ZX07110004).

Availability of data and materials Not applicable.

Ethical Approval Not applicable.

Consent to Participate Not applicable.

Consent to Publish Not applicable.

Competing Interests The authors declare no competing interests.

\section{References}

1. Chen C, Kong M, Wang YY, Shen QS, Zhong JC, Fan CX (2020) Dredging method effects on sediment resuspension and nutrient release across the sediment-water interface in Lake Taihu, China. Environ Sci Pollut Res 27(21):25861-25869

2. Han Q, Tong R, Sun W, Zhao Y, Yu J, Wang G, Shrestha S, Jin Y (2020) Anthropogenic influences on the water quality of the Baiyangdian Lake in North China over the last decade. Sci Total Environ 701:134929

3. Herbeck LS, Unger D, Wu Y, Jennerjahn TC (2013) Effluent, nutrient and organic matter export from shrimp and fish ponds causing eutrophication in coastal and back-reef waters of NE Hainan, tropical China. Cont Shelf Res 57:92-104

4. Horppila J (2019) Sediment nutrients, ecological status and restoration of lakes. Water Res 160:206-208

5. Hu SS, Liu CM, Zheng HX, Wang ZG, Yu JJ (2012) Assessing the impacts of climate variability and human activities on streamflow in the water source area of Baiyangdian Lake. J Geogr Sci 22(5):895-905

6. Huisman J, Codd GA, Paerl HW, Ibelings BW, Verspagen JMH, Visser PM (2018) Cyanobacterial blooms. Nat Rev Microbiol 16(8):471-483 
7. Ji Z, Zhang H, Zhang Y, Chen T, Long Z, Li M, Pei Y (2019) Distribution, ecological risk and source identification of heavy metals in sediments from the Baiyangdian Lake, Northern China. Chemosphere 237:124425

8. Lee SW, Hwang SJ, Lee SB, Hwang HS, Sung HC (2009) Landscape ecological approach to the relationships of land use patterns in watersheds to water quality characteristics. Landsc Urban Plan 92(2):80-89

9. Lu D, Kang Z, Yang B, Dan SF, Zhang D, Zhang P, Huang H, Zhong Q (2020) Compositions and spatiotemporal distributions of different nitrogen species and lability of dissolved organic nitrogen from the Dafengjiang River to the Sanniang Bay, China. Mar Pollut Bull 156:111205

10. Lurling M, Faassen EJ (2012) Controlling toxic cyanobacteria: effects of dredging and phosphorusbinding clay on cyanobacteria and microcystins. Water Res 46(5):1447-1459

11. Lusk MG, Toor GS (2016) Biodegradability and Molecular Composition of Dissolved Organic Nitrogen in Urban Stormwater Runoff and Outflow Water from a Stormwater Retention Pond. Environ Sci Technol 50(7):3391-3398

12. Lv SC, Wang F, Yan WJ, Wang YC, Yu QB, Li YQ (2019) DOC fluorescence properties and degradation in the Changjiang River Network, China: implications for estimating in-stream DOC removal. Biogeochemistry 145(3):255-273

13. Mainali J, Chang $H$ (2018) Landscape and anthropogenic factors affecting spatial patterns of water quality trends in a large river basin, South Korea. J Hydrol 564:26-40

14. Markovic S, Liang AQ, Watson SB, Guo J, Mugalingam S, Arhonditsis G, Morley A, Dittrich M (2019) Biogeochemical mechanisms controlling phosphorus diagenesis and internal loading in a remediated hard water eutrophic embayment. Chem Geol 514:122-137

15. Meng F, Huang G, Yang X, Li Z, Li J, Cao J, Wang Z, Sun L (2013) Identifying the sources and fate of anthropogenically impacted dissolved organic matter (DOM) in urbanized rivers. Water Res 47(14):5027-5039

16. Nobre RLG, Caliman A, Cabral CR, Araujo FC, Guerin J, Dantas F, Quesado LB, Venticinque EM, Guariento RD, Amado AM, Kelly P, Vanni MJ, Carneiro LS (2020) Precipitation, landscape properties and land use interactively affect water quality of tropical freshwaters. Sci Total Environ 716:137044

17. Parsons CT, Rezanezhad F, O'Connell DW, Van Cappellen P (2017) Sediment phosphorus speciation and mobility under dynamic redox conditions. Biogeosciences 14(14):3585-3602

18. Tu L, Jarosch KA, Schneider T, Grosjean M (2019) Phosphorus fractions in sediments and their relevance for historical lake eutrophication in the Ponte Tresa basin (Lake Lugano, Switzerland) since 1959. Sci Total Environ 685:806-817

19. Varol M (2020) Spatio-temporal changes in surface water quality and sediment phosphorus content of a large reservoir in Turkey. Environ Pollut 259:113860

20. Wang F, Wang X, Zhao Y, Yang ZF (2014) Long-term periodic structure and seasonal-trend decomposition of water level in Lake Baiyangdian, Northern China. Int J Environ Sci Technol 11(2):327-338 
21. Wang F, Zhao Y, Xie SL, Li JY (2017) Implication of Nitrifying and Denitrifying Bacteria for Nitrogen Removal in a Shallow Lake. Clean-Soil Air Water 45(4)

22. Welch EB, Cooke GD (2005) Internal phosphorus loading in shallow lakes: Importance and control. Lake Reserv Manag 21(2):209-217

23. Xia LL, Liu RZ, Zao YW (2012) Correlation Analysis of Landscape Pattern and Water Quality in Baiyangdian Watershed. Procedia Environ Sci 13:2188-2196

24. Xie YJ, Yu XJ, Ng NC, Li K, Fang L (2018) Exploring the dynamic correlation of landscape composition and habitat fragmentation with surface water quality in the Shenzhen river and deep bay cross-border watershed. China Ecol Indic 90:231-246

25. Yang C, Yang P, Geng J, Yin H, Chen K (2020) Sediment internal nutrient loading in the most polluted area of a shallow eutrophic lake (Lake Chaohu, China) and its contribution to lake eutrophication. Environ Pollut 262:114292

26. Yu J, Fan C, Zhong J, Zhang Y, Wang C, Zhang L (2016) Evaluation of in situ simulated dredging to reduce internal nitrogen flux across the sediment-water interface in Lake Taihu, China. Environ Pollut 214:866-877

27. Zhang Y, Song C, Ji L, Liu Y, Xiao J, Cao X, Zhou Y (2018) Cause and effect of N/P ratio decline with eutrophication aggravation in shallow lakes. Sci Total Environ 627:1294-1302

28. Zhao Y, Song K, Li S, Ma J, Wen Z (2016) Characterization of CDOM from urban waters in NorthernNortheastern China using excitation-emission matrix fluorescence and parallel factor analysis. Environ Sci Pollut Res 23(15):15381-15394

29. Zhu Y, Jin X, Tang W, Meng X, Shan B (2019) Comprehensive analysis of nitrogen distributions and ammonia nitrogen release fluxes in the sediments of Baiyangdian Lake, China. J Environ Sci 76:319-328

\section{Figures}




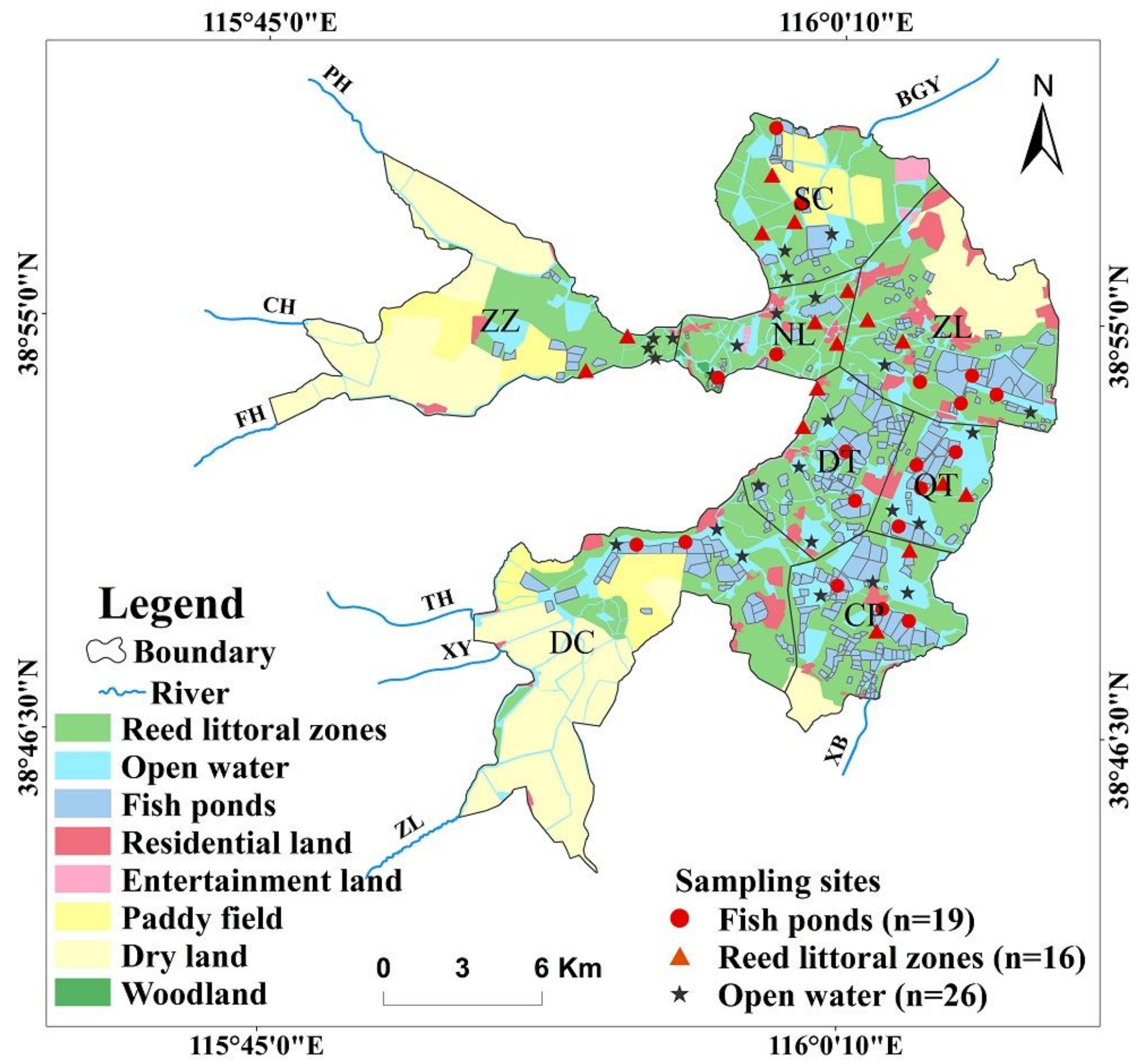

Figure 1

Landscape type distribution, subarea boundaries, and 61 sampling locations within BYD. 

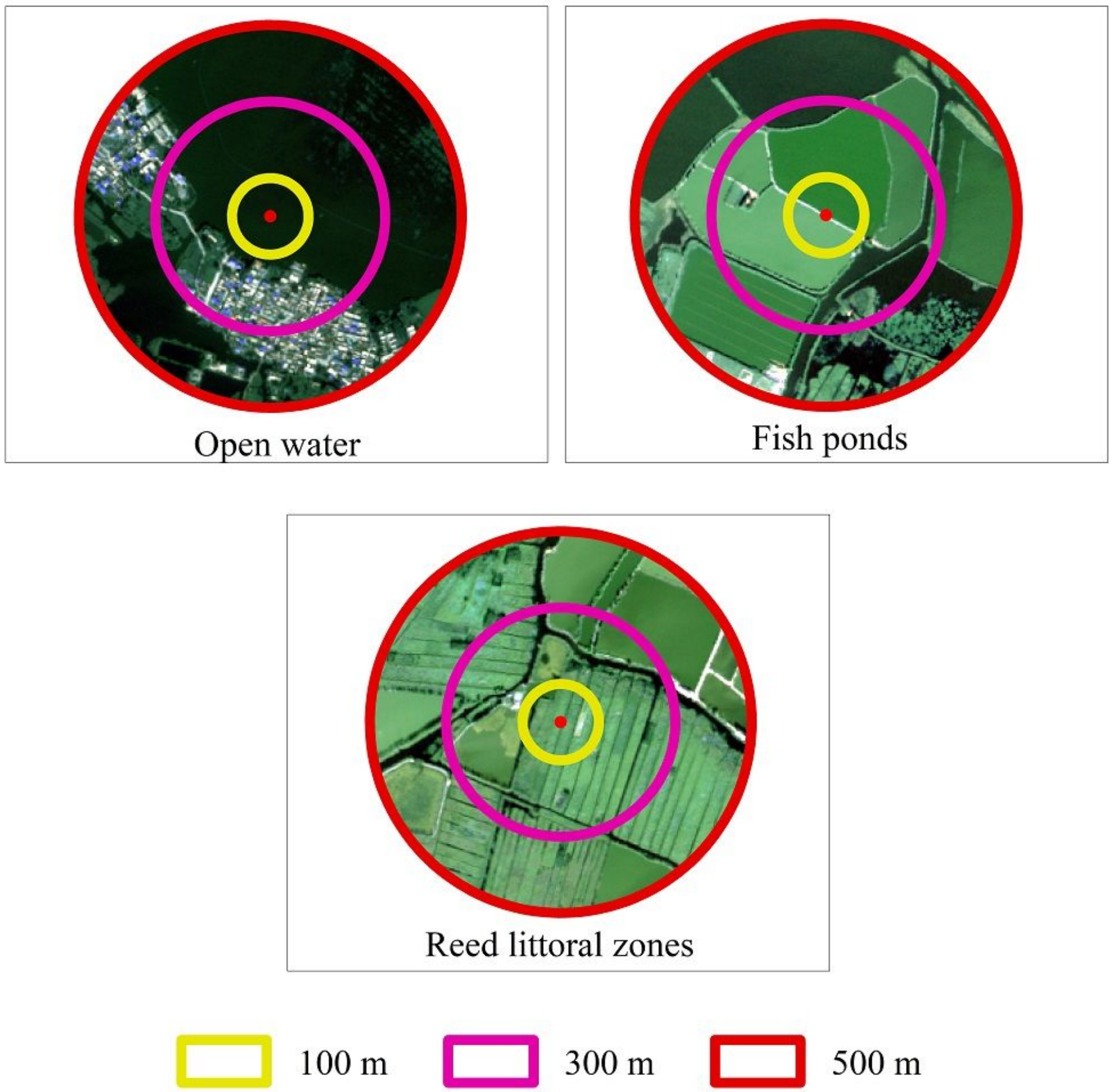

Figure 2

Examples of the three buffer scales used to analyze landscape types. 

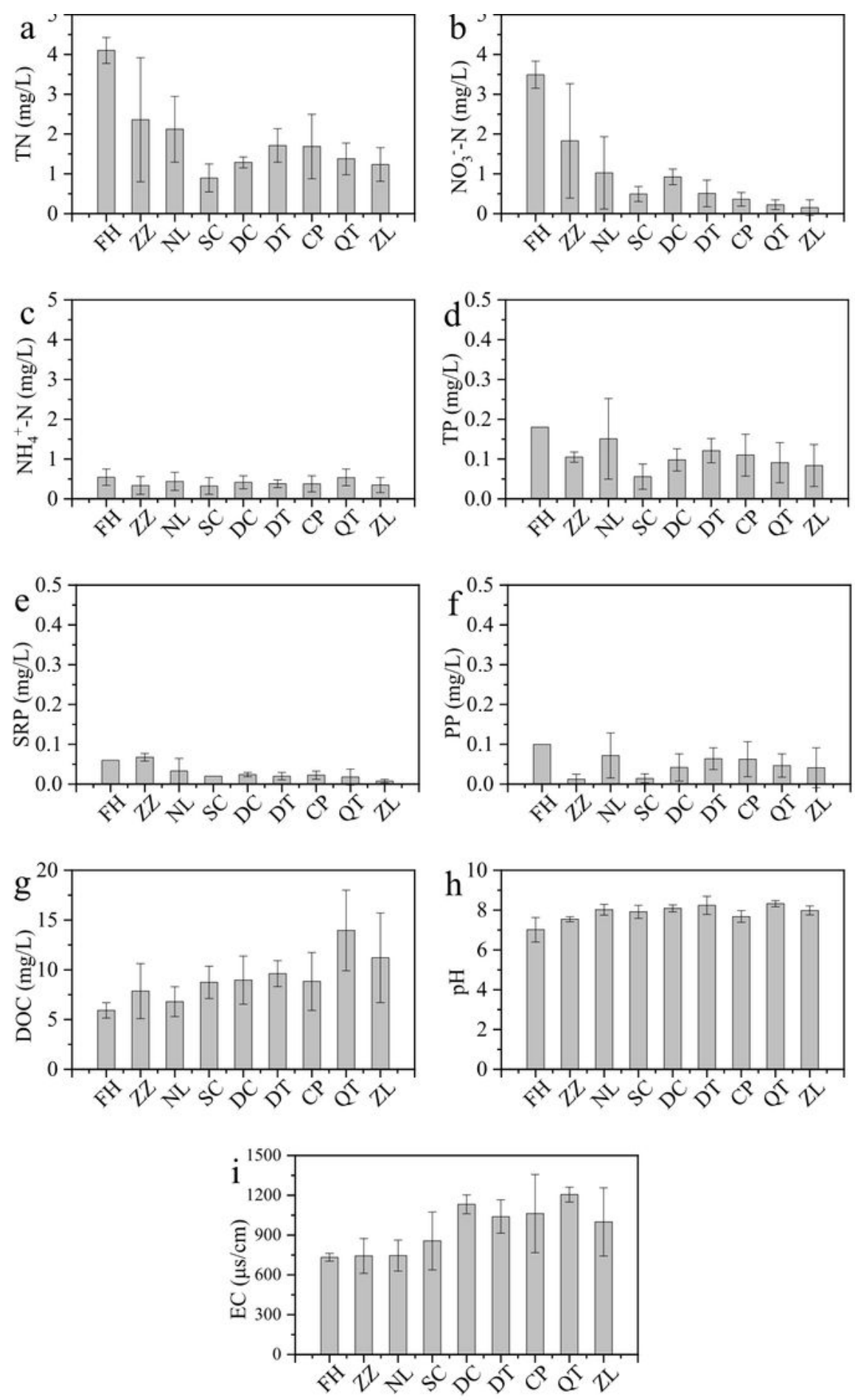

\section{Figure 3}

Spatial variations in nine water quality parameters by subarea: (a) total nitrogen (TN), (b) nitrate nitrogen (NO3-N), (c) ammonia nitrogen (NH4+-N), (d) total phosphorus (TP), (e) particulate phosphorus (PP), (f) soluble reactive phosphorus (SRP), (j) dissolved organic carbon (DOC), (h) pH and (i) electric conductivity (EC). 


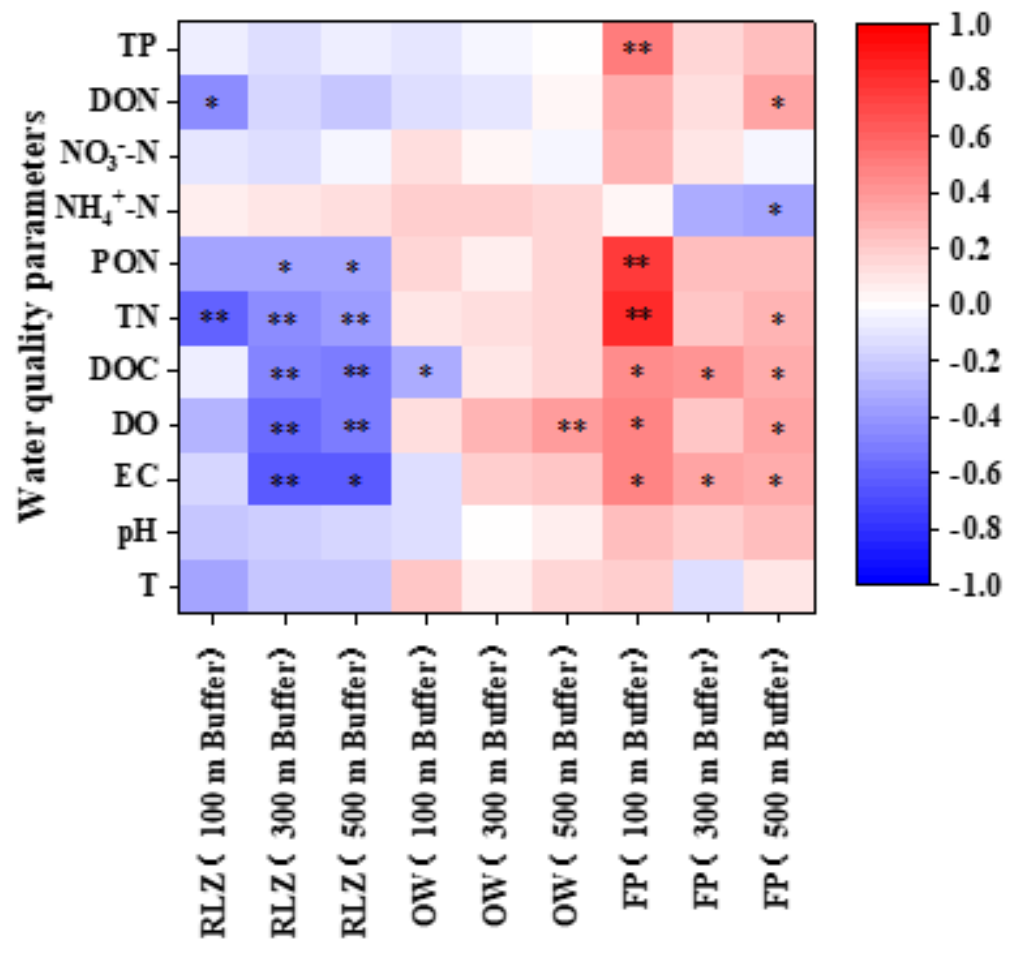

Figure 4

Correlation coefficient for Spearman rank correlations analysis between major water quality parameters concentrations and the area proportion of water landscape type for 100,300, and $500 \mathrm{~m}$ buffers. Blue and red correspond to the negative and positive correlation, respectively. Light color represents lower correlations while darker color represents higher correlations. ' $*$ ' indicates a p-value $<0.05$, and ' $* \star$ ' indicates a p-value $<0.01$. 

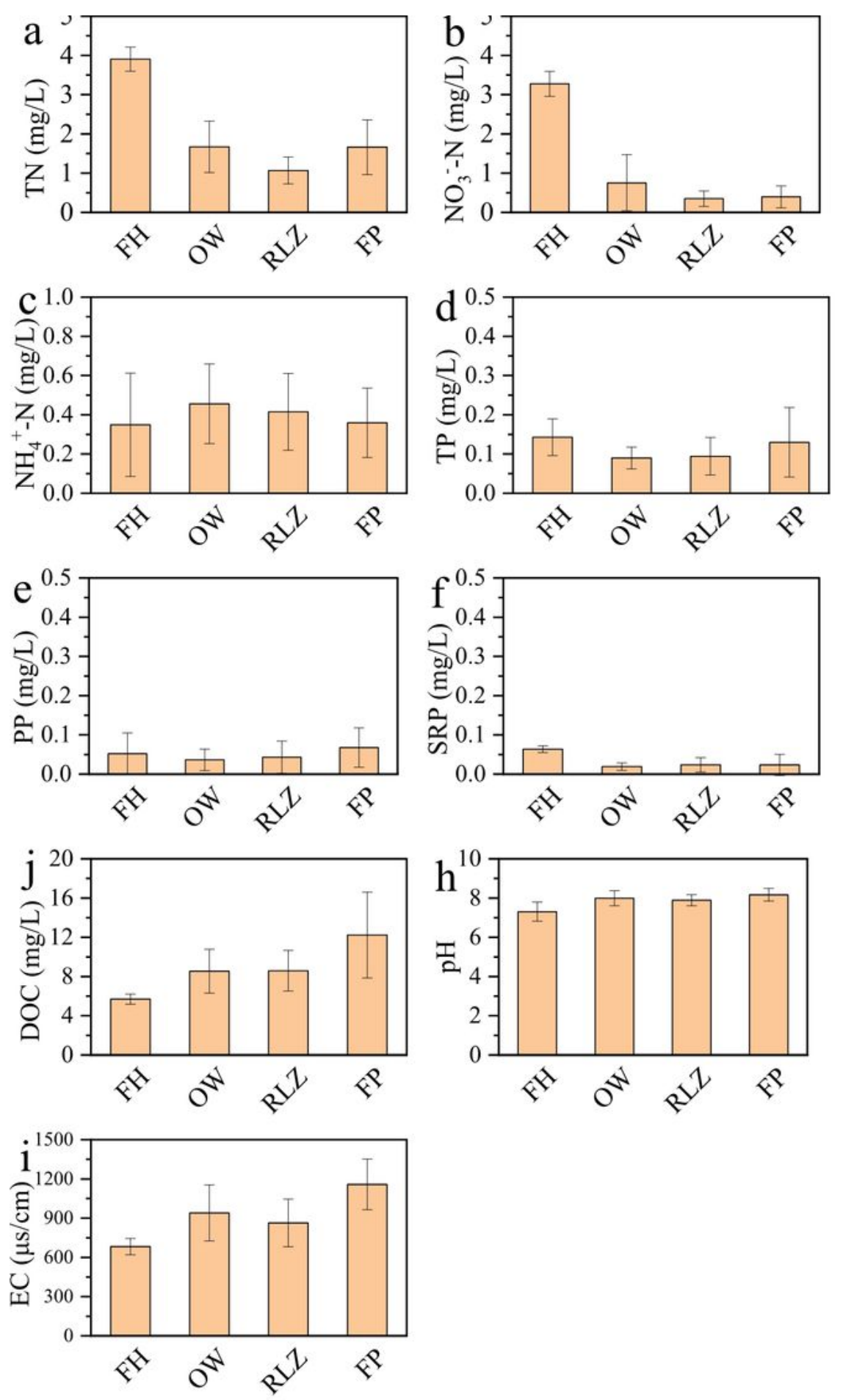

\section{Figure 5}

Variations in water quality parameters by water landscape type: (a) total nitrogen (TN), (b) nitrate nitrogen (NO3--N), (c) ammonia nitrogen (NH4+-N), (d) total phosphorus (TP), (e) particulate phosphorus (PP), (f) soluble reactive phosphorus (SRP), (j) dissolved organic carbon (DOC), (h) pH and (i) electric conductivity (EC). 

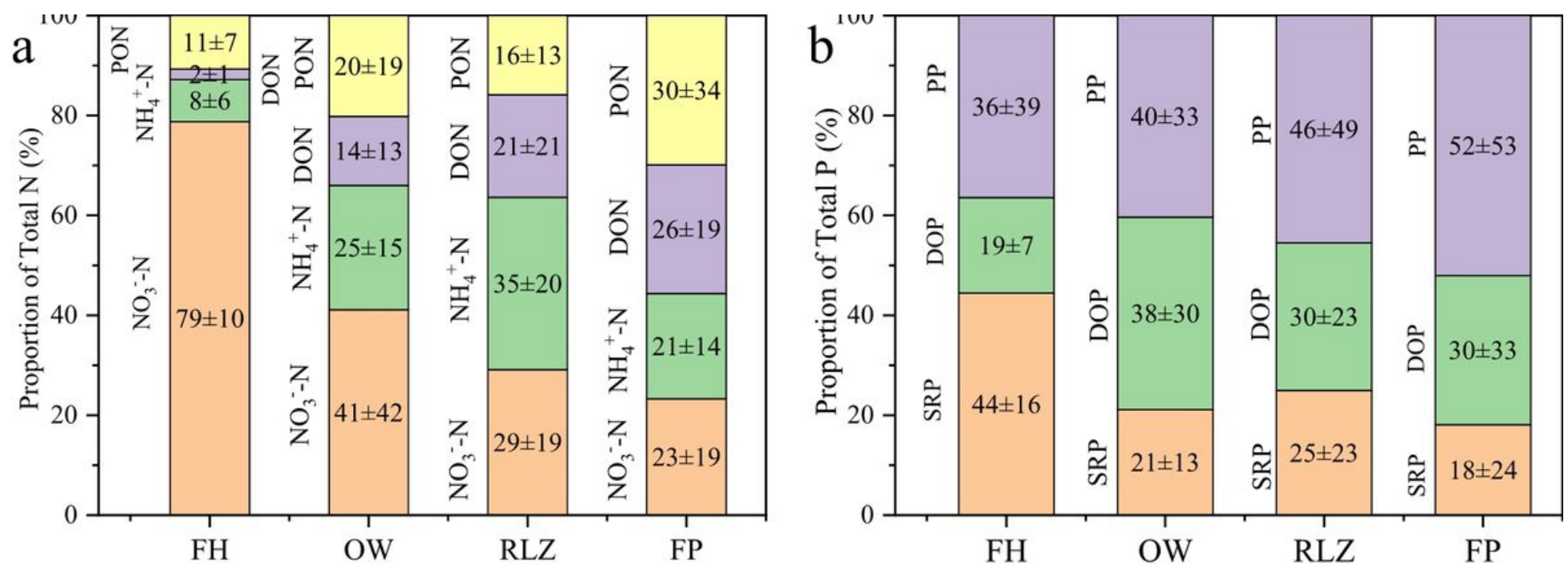

\section{Figure 6}

Variations in (a) TN:TP, (b) DN:DP, and (c) NO3--N:SRP for the four water landscape types 

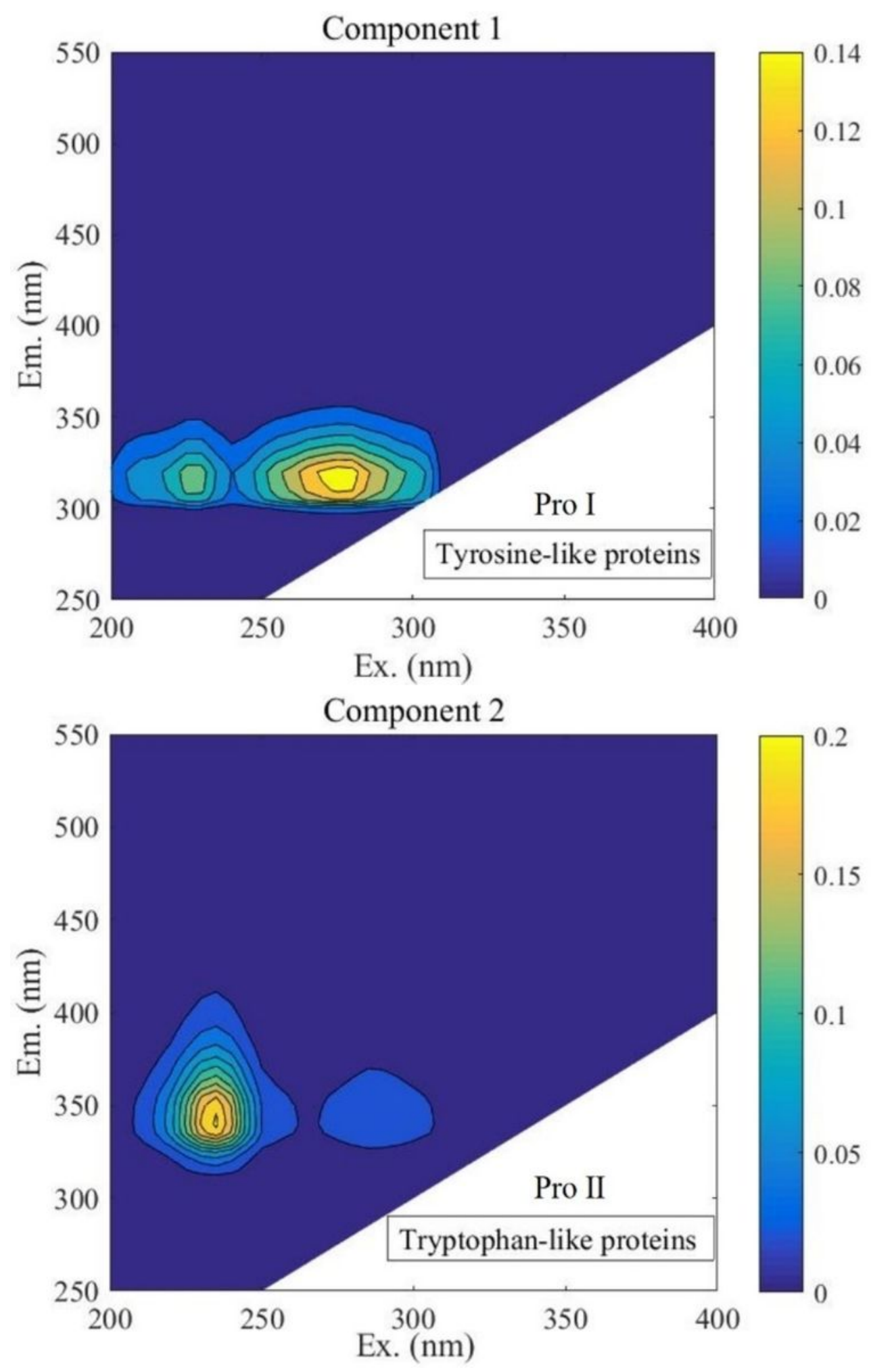

Figure 7

Variations in (a) nitrogen and (b) phosphorus composition in the four water landscape types. Numbers in each box indicate mean \pm standard deviation. 


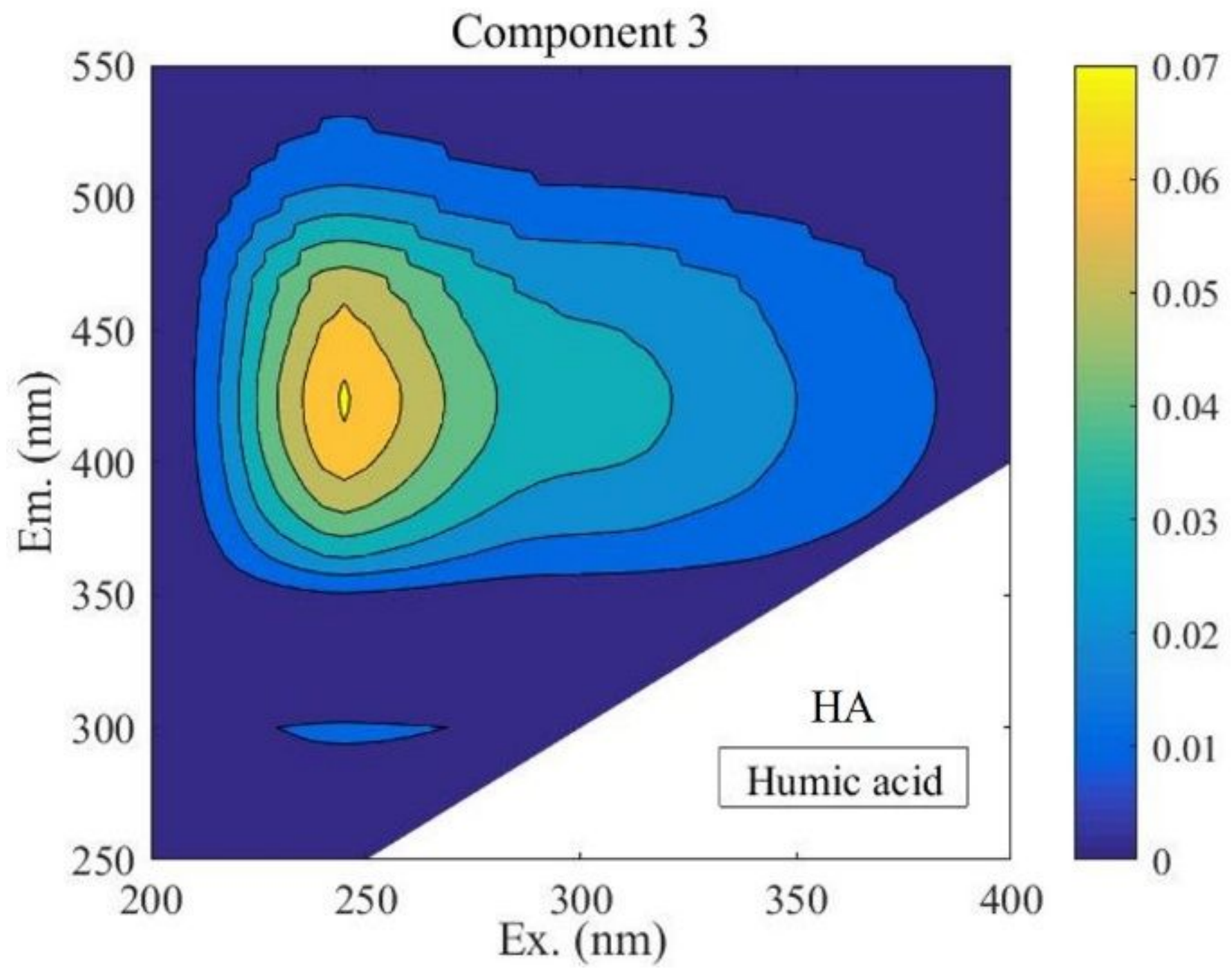

Figure 8

Fluorescence spectra of three components identified by PARAFAC.

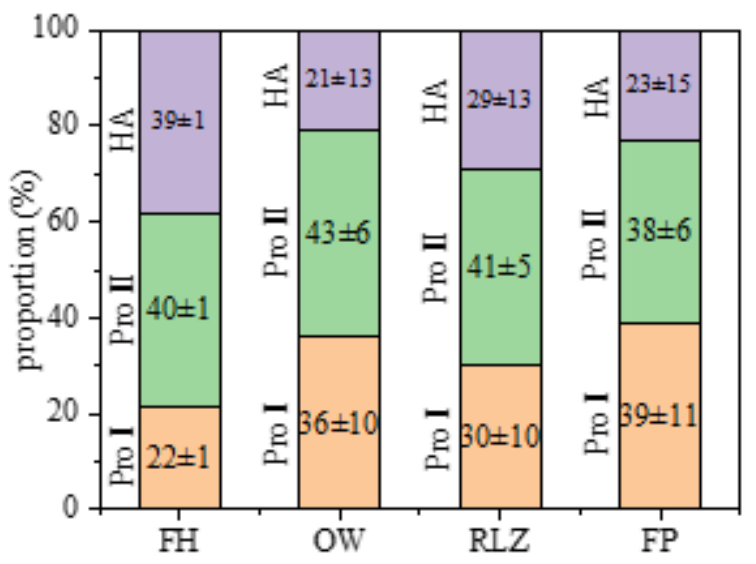

Figure 9

Relative proportions of aquatic DOM fluorescence components in the four water landscape types. Numbers in each box show the mean \pm standard deviation. 